\title{
TISSUE-SPECIFIC MERCURY CONCENTRATIONS IN TWO CATFISH SPECIES FROM THE BRAZILIAN COAST
}

\author{
Juliana de Souza Azevedo*, Jorge Eduardo de Souza Sarkis, \\ Talita Aparecida Oliveira and João Cristiano Ulrich \\ Instituto de Pesquisas Energéticas e Nucleares (IPEN) \\ Centro de Química e Meio Ambiente - CQMA \\ (Av. Prof. Lineu Prestes, 2242, 05508-000 São Paulo, SP, Brasil) \\ *Corresponding author: julianaazevedo_1978@yahoo.com.br
}

\begin{abstract}
A B S T R A C T
Some regions of Brazil have particularly high levels of mercury $(\mathrm{Hg})$ emissions due to industrial activities, and their fish species may therefore suffer high levels of contamination through bioaccumulation. In this paper we assess $\mathrm{Hg}$ contamination in the muscle, liver, gills and blood of two different species of catfish collected from the Cananéia and Santos-São Vicente estuaries, São Paulo State, Brazil. Fish from the most polluted site (Santos-São Vicente) showed higher median $\mathrm{Hg}$ concentrations in both species (Cathorops spixii - liver: $1530 \mu \mathrm{g} \mathrm{Kg}^{-1}$, muscle: $327 \mu \mathrm{g} \mathrm{Kg}^{-1}$ and gill: $101 \mu \mathrm{g} \mathrm{Kg}^{-1}$; Genidens genidens - liver: $2617 \mu \mathrm{g} \mathrm{Kg}^{-1}$, muscle: $393 \mu \mathrm{g} \mathrm{Kg}-1$ and gill: $118 \mu \mathrm{g} \mathrm{Kg}^{-1}$ ). Multivariate analysis revealed the importance and influence of key biological variables (size, condition, etc.) in determining the overall level of $\mathrm{Hg}$ and its distribution within different tissues.
\end{abstract}

\section{RESUMO}

\begin{abstract}
Algumas regiões do Brasil apresentam, altos níveis de emissões de mercúrio $(\mathrm{Hg})$ devido às atividades industriais, e suas espécies de peixes podem, portanto, estar expostos a elevados níveis de contaminação por meio da bioacumulação. Neste trabalho avaliamos a contaminação por Hg no músculo, fígado, brânquias e sangue de duas espécies de bagres coletados nos estuários de Cananéia e Santos-São Vicente, São Paulo, Brasil. Peixes amostrados no local mais poluído (Santos-São Vicente) mostraram maiores concentrações de $\mathrm{Hg}$ em ambas as espécies (Cathorops spixii - fígado: $1530 \mu \mathrm{g} \mathrm{Kg}^{-1}$, músculo: $327 \mu \mathrm{g} \mathrm{Kg}^{-1}$ e brânquias: $101 \mu \mathrm{g} \mathrm{Kg}^{-1}$; Genidens genidens - fígado: $2617 \mu \mathrm{g}$ $\mathrm{Kg}^{-1}$, músculo: $393 \mu \mathrm{g} \mathrm{Kg}^{-1}$ e brânquias: $118 \mu \mathrm{g} \mathrm{Kg}^{-1}$ ). Análises multivariadas revelaram a importância e influência das principais variáveis biológicas (tamanho, condição, etc.) no teor geral de $\mathrm{Hg}$ e sua distribuição nos diferentes tecidos.
\end{abstract}

Descriptors: Mercury, Bioaccumulation, Biomonitoring, Data fields, Catfish, Estuaries.

Descritores: Mercúrio, Bioacumulação, Biomonitoramento, Dados de campo, Bagres, Estuários.

\section{INTRODUCTION}

Mercury $(\mathrm{Hg})$ is a non-essential and highly toxic element that occurs both naturally and as a contaminant introduced into the environment. Different anthropogenic activities, particularly gold mining and the chlor-alkali industry, contribute to the environmental concentrations of this metal in the aquatic system (FURNESS; RAINBOW, 1990; HEATH, 1995).

Due to its capability to bioaccumulate within aquatic food chains (KOJADINOVIC et al., 2007; SARDANS et al., 2010), $\mathrm{Hg}$ is considered one of the most important elements in aquatic toxicology (BOENING, 2000). Living organisms, especially those occupying higher trophic levels (e.g. top predators), are frequently the best indicators of environmental contaminants because they bioaccumulate toxins in body tissues (SCHNEIDER et al., 2009). Studies of mercury contamination in organisms from coastal environments have been thoroughly examined in this respect, specifically regarding bioaccumulation in predatory fish species (ADAMS et al., 2010; COELHO et al., 2010). Mercury accumulation has also been studied in relation to food-chain transfer and the potential risk to human health (WANG et al., 2010). Mercury uptake by fish is a cumulative process that is influenced by biomagnifications through food webs, habitat preferences (i.e. pelagic, demersal or benthic habit) and the biological characteristics of the species (HARMELIN-VIVIEN et al., 2009). 
The distribution of $\mathrm{Hg}$ in the tissues of fish and the correlation of total $\mathrm{Hg}$ levels with age, length and sex is very well known (AZEVEDO et al., 2009a; ENDO et al., 2009; COELHO et al., 2010). Karels et al. (1998) and Kojadinovic et al. (2007) suggest that fish from polluted sites usually show an increase in the hepatic somatic index (HSI) - although it should be noted that this association is extremely variable. Furthermore, the condition factor (CF) broadly indicates that a living organism is in good physiological condition (ADAMS; RYON, 1994).

The Santos-São Vicente estuary is located in the central coastal area of Brazil in the southeast of the State of São Paulo $\left(24^{\circ} 00^{\prime} \mathrm{S} ; 46^{\circ} 21^{\prime} \mathrm{W}\right)$. The climate is typical of the Atlantic tropical rain forest. Industrial activities and tourism are economically important to the region, and a large population density contributes to the release of high levels of domestic sewage. Santos Bay is a part of the estuarine Santos-São Vicente complex and some authors (BOLDRINI; NAVAS-PEREIRA, 1987; BRAGA et al., 2003; AGUIAR;BRAGA, 2007) have reported high concentrations of different chemical compounds introduced into the Santos Bay. This system also contains the largest commercial harbor in South America and, with approximately 1100 industries (such as fertilizers and pharmaceuticals), is one of the most important petrochemical and metallurgical industrial areas in Brazil. The rapid increase in urbanization and industrialization, mainly in the last 50 years, has caused the degradation of the coastal mangrove habitat through contamination with effluent from industrial and domestic sources, and solid waste. Thus, the area has been subject to a gradual process of chemical and biological contamination over recent decades as a direct result of an increase in industrial activities and the release of sewage. All of these anthropogenic sources contribute directly or indirectly to the concentration of chemical contaminants in the local environment.

In contrast to the Santos-São Vicente estuary, the Cananéia estuary is subject to minimal anthropogenic influence and is frequently used as an environmental reference point for marine biomonitoring studies in the State of São Paulo (AZEVEDO et al., 2009b). However, in recent years some studies have indicated the presence of toxic metals, including $\mathrm{Hg}$, in this region. The presence of $\mathrm{Hg}$ in the estuary can be partly explained by the presence of an abandoned gold mine and the fertilizer industry located in Iguape, in the northern portion of the estuary. Nevertheless, it is important to note that $\mathrm{Hg}$ can come from a wide variety of non-point sources such as transport or dispersion through the plume, transportation in river sediments, and the tissues of migrating aquatic species (WEINER; SPRY, 1996; FITZGERALD et al., 1998).
Many studies report $\mathrm{Hg}$ concentrations in fish (LIMA et al., 2005; KOJADINOVIC et al., 2007; KASPER et al., 2009; COELHO et al., 2010; SARDANS et al., 2010; SHAH et al., 2010). However, there is a general lack of information concerning the numerically and ecologically important Ariidae catfish. Two of the commonest species in this family, Cathorops spixii and Genidens genidens, have a wide geographical distribution along the Atlantic coast of South America, ranging from Belize to the Southern Brazilian coast. C. spixii is the most common catfish on the Brazilian Coast (TIJARO et al., 1998). These benthic fish feed mainly within the pelitic fraction where the bioavailability of contaminants is typically higher. There have been very few studies on the accumulation and effects of pollutants in $C$. spixii. One previous study demonstrated varying concentrations of $\mathrm{Hg}$ concentrations in muscle of $C$. spixii (AZEVEDO et al., 2009a). However, there is no information about $\mathrm{Hg}$ contamination in $G$. genidens either from the Santos-São Vicente or Cananéia estuaries. G. genidens is the second most abundant Ariidae species in the Santos-São Vicente estuary (SCHMIDT et al., 2008), and may therefore be very useful for evaluating the accumulation of contaminants and biomonitoring studies.

The aim of the present study was to assess total and within-tissue $\mathrm{Hg}$ concentrations in $C$. spixii and $G$. genidens from one site in Southern Cananéia and two sites in the Santos-São Vicente estuary. Multivariate analysis was used as a tool to determine the influence of various key biological variables (a combination of morphological traits and physiological indices) on relative concentrations of $\mathrm{Hg}$ in the tissues of fish from different sites and of different genders.

\section{Material and Methods}

Sample Collection

A total of 46 specimens of Cathorops spixii and 38 of Genidens genidens were collected in two consecutive campaigns during July and August 2009 using gillnets of $20 \mathrm{~mm}$ mesh. Individuals were collected in the industrial $(n=27)$ and domestic $(n=37)$ areas within the Santos-São Vicente estuary and from the Cananéia estuary $(n=20)$, both located in São Paulo State, Brazil. It was not possible to collect $G$. genidens in Cananéia due to logistical problems. The industrial area is located in the inner area of the estuary near the Cosipa industry (COS) located in Cubatão city, while the domestic area is located in the Araçarana site (ARA) that is an area that now contains dwellings raised on stilts and was previously a site for dumping household waste (Fig. 1). 


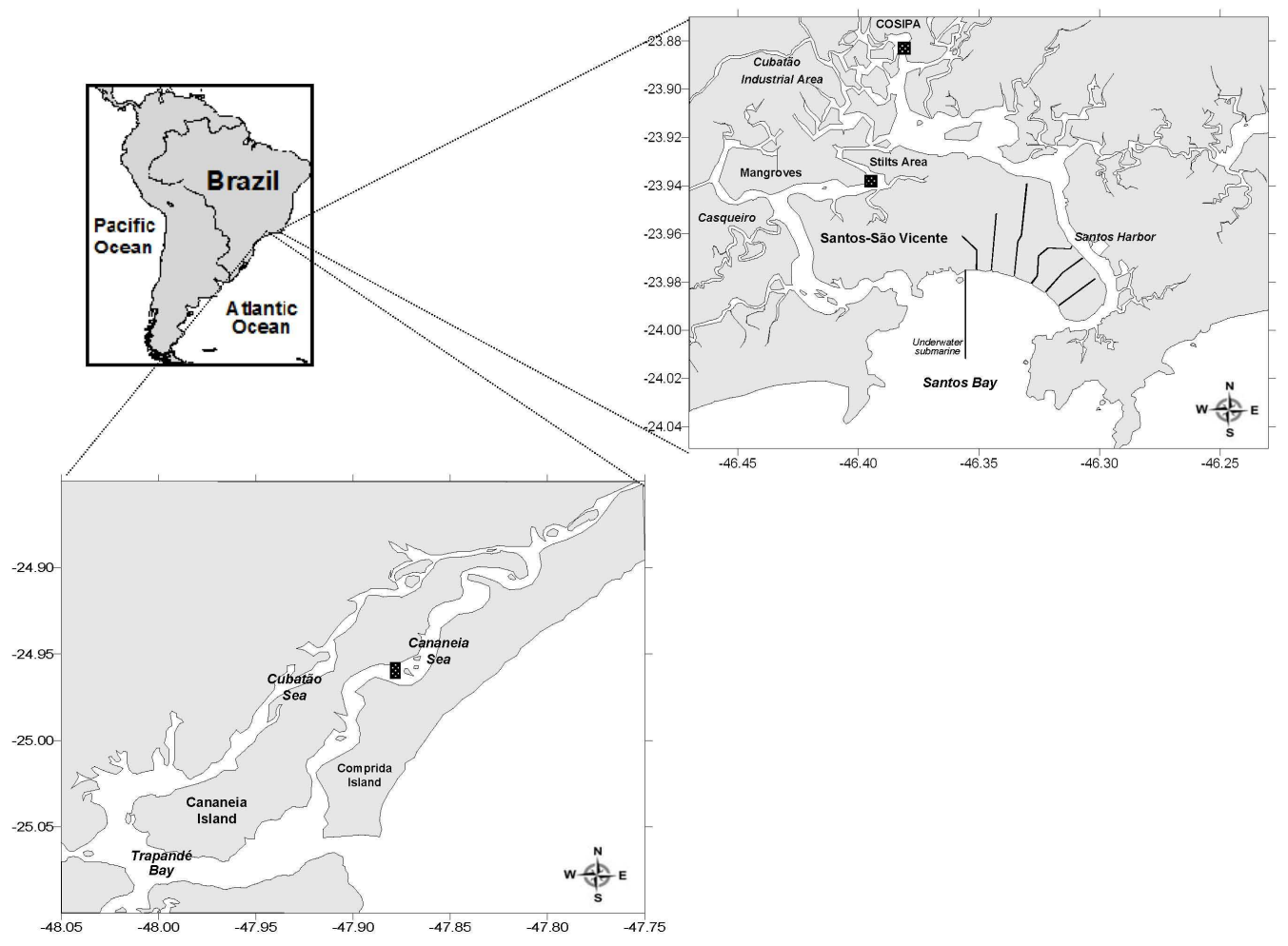

Fig. 1. Sampling sites showing Santos-São Vicente and Cananéia estuaries, São Paulo, southeast coast of Brazil.

After collection, the fish were identified, kept in water from the sampling site of origin and transported to the laboratory at the Nuclear and Energy Research Institute. Individuals were then anesthetized with benzocaine ( $2 \%$ in water), blood samples were obtained by caudal vein puncture using a syringe with heparin, and then the fish were killed by spinal section. Morphometric data were recorded for total length (TL) and total weight (TW), the fish were then opened to check gender by ovarian and testicular morphological characteristics (position, color, and size of gonads besides the presence of veins, eggs and sperm) in accordance with the methods described by Figueiredo and Menezes (1978). Finally, tissue samples were taken. Epaxial muscle, from dorsal fish surface, gills and liver were removed from each specimen, washed with distilled water, packed in identified polyethylene bags and kept at $-20^{\circ} \mathrm{C}$ for subsequent $\mathrm{Hg}$ analysis.

\section{Somatic Indexes}

The hepatic somatic index was calculated as HSI $=[$ liver weight $(\mathrm{g}) /$ body weight $(\mathrm{g})] \mathrm{x} 100$. The condition factor $(\mathrm{CF})$ was calculated as $\mathrm{CF}=[$ body weight $(\mathrm{g}) /$ length $\left.(\mathrm{mm})^{\mathrm{b}}\right]$ in accordance with Vazzoler
(1996). Where: $b=$ angular coefficient of the relationship between weight and length.

\section{Mercury Analysis}

$\mathrm{Hg}$ determination was performed by using the Flow Injection Cold Vapor Atomic Absorption Spectrometry (FI-CV-AAS) (Varian model spectra AA-220-Fast Sequencial). Preliminary tests were performed in order to identify the amount of each tissue to be used for analysis. Based on these results, the following amounts of each tissue were used: muscle - approximately $1.0 \mathrm{~g}$; liver -0.2 to $0.5 \mathrm{~g}$; gill 0.2 to $1.0 \mathrm{~g}$; and blood -0.6 to $1.0 \mathrm{~g}$.

After weighting, the three tissues were placed in glass flasks and digested in a concentrated solution of $65 \% \mathrm{HNO} 3,98 \% \mathrm{H} 2 \mathrm{SO} 4$ and $70 \% \mathrm{HClO} 4$ (1:2:1). All acids were obtained from Merck. The analytical procedure used (wet digestion) follows the method described by Lima et al. (2005). The detection and quantification limits were $2 \mu \mathrm{g} \mathrm{Kg}^{-1}$ and $15 \mu \mathrm{g} \mathrm{Kg}$ 1, respectively. Total $\mathrm{Hg}$ determination was validated with certified standard reference material (Dogfish muscle DORM-2: National Research Canada Council). Mercury concentrations were reported as $\mu \mathrm{g} \mathrm{Kg}^{-1}$ wet weight. 
Quality was assured by performing daily $\mathrm{Hg}$ analysis of the certified reference material Dorm-2 with certified $\mathrm{Hg}$ concentration of $4.64 \pm 0.26 \mathrm{mg}$ $\mathrm{Kg}^{-1}$. The mean value $(n=6)$ was $4.61 \pm 0.07 \mathrm{mg} \mathrm{Kg}^{-1}$ with a recovery of $99 \%$ at 0.05 significance level, within the confidence interval of the certified level. The analytical results showed high levels of precision and accuracy.

\section{Statistical Analysis}

Statistic for Windows 5.0 was used for analysis. Observed differences between mercury levels in the tissues were verified by discriminant analysis. Morphological data and somatic indices were analyzed by Kruskal-Wallis ANOVA test. Spearman's correlation (rs) was used to verify the interdependence between the variables. A significance level of $p<0.05$ was considered for all tests. Due to the individual variability of mercury levels in the different tissues, results are expressed as median values using box plots.

In order to verify possible correlations among variables, multivariate analysis was performed using the biological parameters (TL, TW, CF, and HSI) and Hg levels in the different tissues (Hgblood, Hgliver, Hggill, Hgmuscle) for each Ariidae species from the three sampling sites (Cananéia estuary, and the Industrial and Araçarana areas in the Santos-São Vicente estuary). For this purpose, principal component analysis (PCA) was used. This is an ordination method for the calculation of the covariance or correlation matrix of original measurement data. Group definition was made from the eigenvalues, the PCA variable loadings and PCA variable loading on each axis. Due to the great differences between the values of the tested variables, data were standardized from the similarity matrix (generated by the program itself) and variables and cases plotted on the graph. Tolerance of eigenanalysis set was defined for each PCA.

\section{RESULTS}

Morphological Data and Somatic Index

Morphological data and somatic index are summarized in Table 1. Fish from the Cananéia estuary showed greater total length and total weight (TL: $302-411 \mathrm{~mm}$, TW: $236-690 \mathrm{~g}$ ) than fish from the industrial (TL: 171-224 mm, TW: 51-104 g) and domestic (TL: 128-317 mm, TW: 19-328 g) areas. All fish collected were adults, with active gonadal maturation, including spawning and post-spawning individuals.

In neither of the Ariidae catfish (C. spixii and $G$. genidens) were any significant differences $(p>0.05)$ found in mean HSI and CF values between gender and sites. Furthermore, no significant differences $(p>0.05)$ were found for morphological data or somatic indices either in $C$. spixii or in $G$. genidens.

Table 1. Morphological data and somatic indices are presenting as mean \pm sdv for C. spixii and G. genidens from each sampling site.

\begin{tabular}{|c|c|c|c|c|c|c|}
\hline \multicolumn{7}{|c|}{ C. spixii } \\
\hline \multirow{3}{*}{ Cananéia } & & $n$ & $\mathrm{TL}(\mathrm{mm})$ & TW (g) & HSI & $\mathrm{CF}$ \\
\hline & M & 05 & $328 \pm 33^{\mathrm{a}}$ & $312 \pm 107^{\mathrm{a}}$ & $1.65 \pm 0.19^{c}$ & $0.86 \pm 0.04^{\mathrm{d}}$ \\
\hline & $\mathrm{F}$ & 15 & $362 \pm 35^{\mathrm{a}}$ & $465 \pm 145^{\mathrm{a}}$ & $1.73 \pm 0.26^{\mathrm{c}}$ & $0.95 \pm 0.07^{\mathrm{d}}$ \\
\hline \multirow[t]{2}{*}{ Domestic } & M & 07 & $185 \pm 19^{a}$ & $62 \pm 20^{\mathrm{ab}}$ & $1.55 \pm 0.28^{c}$ & $0.96 \pm 0.05^{\mathrm{d}}$ \\
\hline & $\mathrm{F}$ & 14 & $200 \pm 13^{\mathrm{a}}$ & $79 \pm 15^{b}$ & $1.27 \pm 0.15^{\mathrm{c}}$ & $0.97 \pm 0.08^{\mathrm{d}}$ \\
\hline Industrial & $\mathrm{F}$ & 05 & $240 \pm 75^{\mathrm{a}}$ & $171 \pm 125^{\mathrm{ab}}$ & $1.73 \pm 0.27^{\mathrm{c}}$ & $0.97 \pm 0.08^{\mathrm{d}}$ \\
\hline \multicolumn{7}{|c|}{ G. genidens } \\
\hline \multirow{3}{*}{ Domestic } & & $n$ & $\mathrm{TL}(\mathrm{mm})$ & TW (g) & HSI & $\mathrm{CF}$ \\
\hline & $\mathrm{M}$ & 09 & $239 \pm 58^{\mathrm{a}}$ & $148 \pm 107^{a b}$ & $1.34 \pm 0.3^{c}$ & $0.90 \pm 0.09^{\mathrm{d}}$ \\
\hline & $\mathrm{F}$ & 07 & $197 \pm 24^{\mathrm{a}}$ & $72 \pm 32^{b}$ & $1.32 \pm 0.12^{\mathrm{c}}$ & $0.89 \pm 0.07^{\mathrm{d}}$ \\
\hline \multirow[t]{2}{*}{ Industrial } & $\mathrm{M}$ & 11 & $215 \pm 29^{a}$ & $95 \pm 40^{\mathrm{ab}}$ & $1.56 \pm 0.58^{c}$ & $0.89 \pm 0.06^{\mathrm{d}}$ \\
\hline & $\mathrm{F}$ & 11 & $223 \pm 55^{\mathrm{a}}$ & $95 \pm 50^{\mathrm{ab}}$ & $1.50 \pm 0.46^{\mathrm{c}}$ & $0.84 \pm 0.15^{d}$ \\
\hline
\end{tabular}

M: male; F: female; TL: total length; TW: total weigh; HSI: hepatic somatic index; CF: condition factor. Distinct letters indicate significant differences by Kruskal-Wallis test ( $\mathrm{p}<0.05)$. 
Tissue $\mathrm{Hg}$ Concentrations

Median values of $\mathrm{Hg}$ in muscle, liver and gill tissues of $C$. spixii and $G$. genidens are shown in Figure 2. Fish from the industrial area site (COS) were characterized by higher $\mathrm{Hg}$ values in both species $(C$. spixii - liver: $1114 \mu \mathrm{g} \mathrm{Kg}^{-1}$, muscle: $267 \mu \mathrm{g} \mathrm{Kg}^{-1}$ and gill: $111 \mu \mathrm{g} \mathrm{Kg}^{-1}$; G. genidens - liver: $1986 \mu \mathrm{g} \mathrm{Kg}^{-1}$, muscle: $392 \mu \mathrm{g} \mathrm{Kg}^{-1}$ and gill: $121 \mu \mathrm{g} \mathrm{Kg}^{-1}$ ). In general, the lowest $\mathrm{Hg}$ values were obtained for the fish from the domestic site (C. spixii - liver: $586 \mu \mathrm{g} \mathrm{Kg}^{-1}$, muscle: $95 \mu \mathrm{g} \mathrm{Kg}^{-1}$ and gill: $70 \mu \mathrm{g} \mathrm{Kg}^{-1}$; G. genidens liver: $372 \mu \mathrm{g} \mathrm{Kg}^{-1}$, muscle: $102 \mu \mathrm{g} \mathrm{Kg}^{-1}$ and gill: $54 \mu \mathrm{g}$ $\mathrm{Kg}^{-1}$ ).

The median $\mathrm{Hg}$ value for males of $C$. spixii from the Cananéia estuary shows higher levels than the $\mathrm{Hg}$ concentrations for females (males - liver: 1036 $\mu \mathrm{g} \mathrm{Kg}{ }^{-1}$, muscle: $194 \mu \mathrm{g} \mathrm{Kg}^{-1}$, gill: $112 \mu \mathrm{g} \mathrm{Kg}^{-1}$, blood: $65 \mu \mathrm{g} \mathrm{Kg}{ }^{-1}$; females: liver: $643 \mu \mathrm{g} \mathrm{Kg}{ }^{-1}$, muscle: $150 \mu \mathrm{g} \mathrm{Kg}^{-1}$, gill: $51 \mu \mathrm{g} \mathrm{Kg}^{-1}$, blood: $54 \mu \mathrm{g}$ $\mathrm{Kg}^{-1}$ ), but these differences were only statistically significant in the liver and gill samples $(p<0.05)$. Additionally, the median values for specimens from the domestic site (ARA) did not show significant differences regarding gender $(p>0.05)$.
In $G$. genidens, the $\mathrm{Hg}$ values for males and females from the industrial area (COS) and domestic sites (ARA) did not differ in $\mathrm{Hg}$ content $(p>0.05)$, possibly because of the high degree of individual variability. Generally, the lowest $\mathrm{Hg}$ levels were observed in the gills (C. spixii: $23 \mu \mathrm{g} \mathrm{Kg}^{-1}, G$. genidens: $\left.15 \mu \mathrm{g} \mathrm{Kg}^{-1}\right)$ and the highest in the liver $(C$. spixii: $3493 \mu \mathrm{g} \mathrm{Kg}^{-1}$, G. genidens: $\left.9005 \mu \mathrm{g} \mathrm{Kg}^{-1}\right)$. The $\mathrm{Hg}$ level interval present in muscle was $49-448 \mu \mathrm{g}$ $\mathrm{Kg}^{-1}$ and 32-544 $\mu \mathrm{g} \mathrm{Kg}^{-1}$ for C. spixii and G. genidens, respectively. Finally, G. genidens specimens showed a higher $\mathrm{Hg}$ accumulation in their tissues, especially the liver, than $\operatorname{did} C$. spixii.

A PCA was performed for all the biological variables and $\mathrm{Hg}$ levels in both species (Fig. 3). The PCA accounted for $81 \%$ of total variance, of that $53 \%$ of $81 \%$ associated with $\mathrm{PC} 1$ and $28 \%$ of $81 \%$ with $\mathrm{PC} 2$. Two groups could be distinguished in $\mathrm{PC} 1$ : COS - HgliverGg and HgmuscGg; CAN - HgliverCs, HgmuscCs, WCs and CFCs. By contrast, in PC2 there was one group consisting of ARA - TWGg, TLGg, HSIGg, CFGg and Hggill. The distinction between $C$. spixii $(\mathrm{Cs})$ and $G$. genidens $(\mathrm{Gg})$ in the different areas could thus be ascertained.

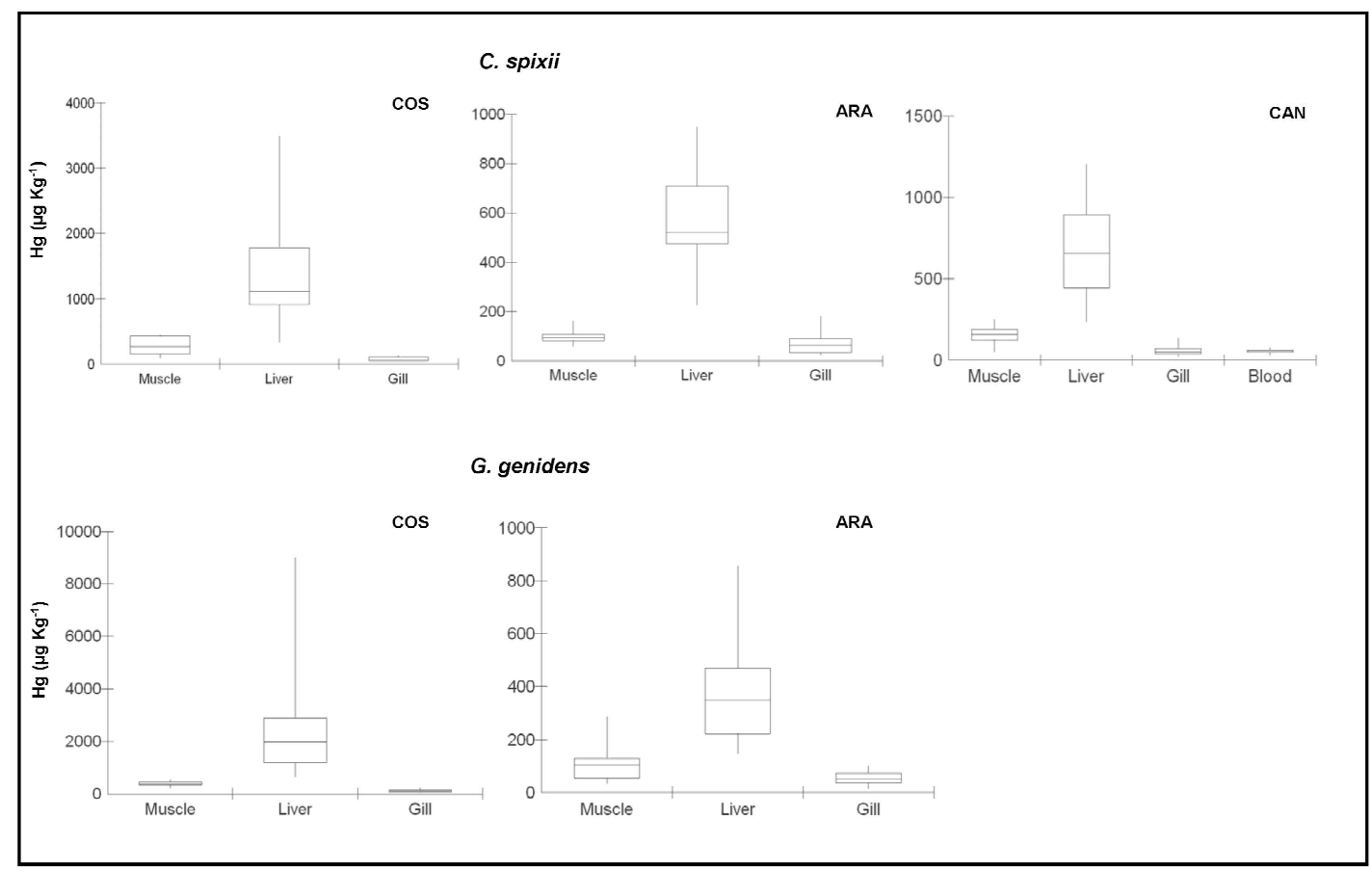

Fig. 2. Boxplot of the median $\mathrm{Hg}$ concentrations in muscle, liver and gill of $C$. spixii and G. genidens sampled in Cananéia (CAN) and within two sites of the Santos-São Vicente estuary, for instance domestic (ARA) and industrial (COS) areas. 


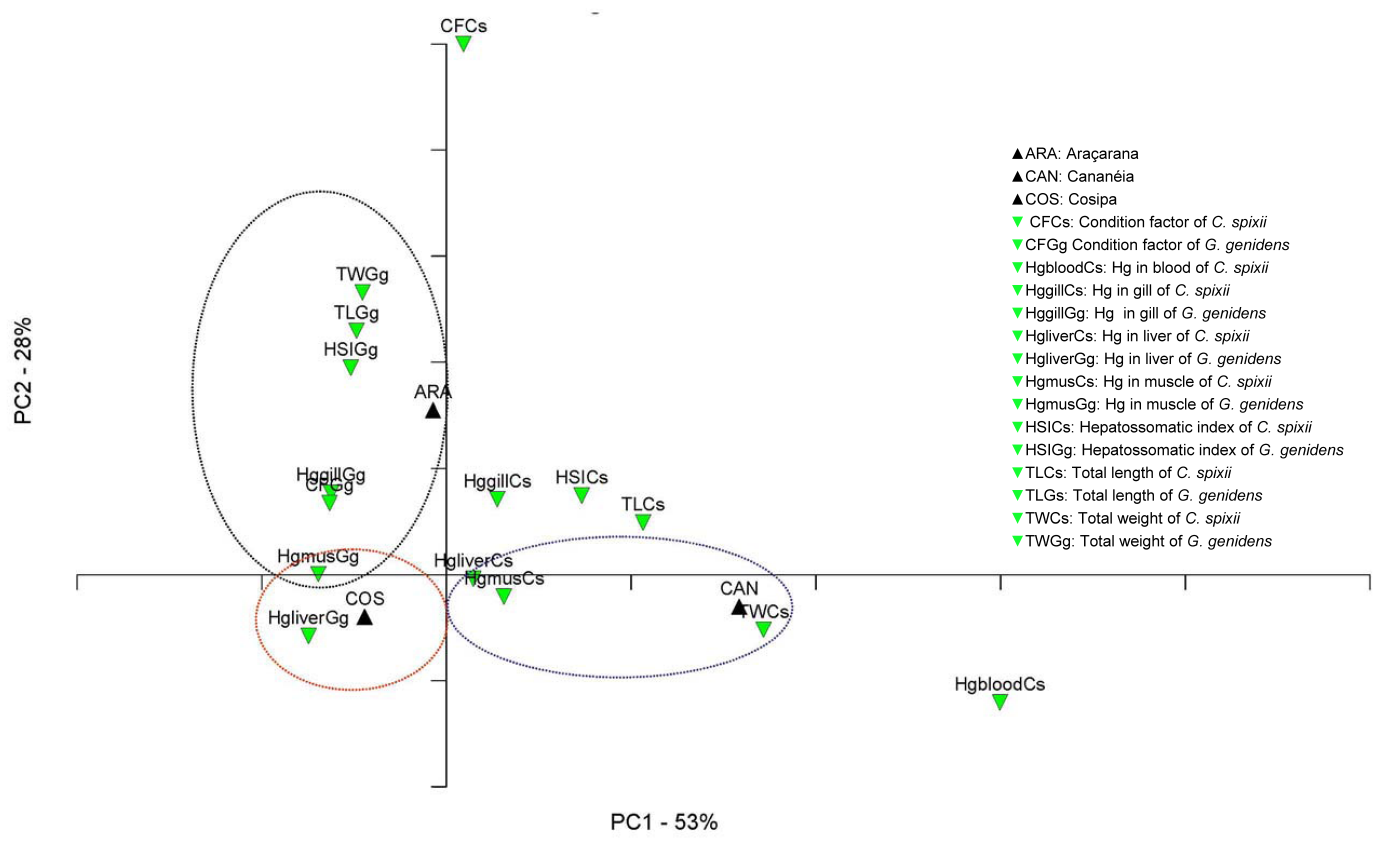

Fig. 3. Principal Components Analysis (PCA) of the biological variables (TL, TW, HSI, CF) and Hg concentrations in gill (Hggill), liver (Hgliver), muscle (Hgmus) and blood (Hgblood) of C. spixii (Cs) and G. genidens (Gg) from Cananéia (CAN), industrial (COS) and domestic (ARA) areas.

Figures 4 and 5 show the PCA for biological variables and $\mathrm{Hg}$ levels in C. spixii and G. genidens by gender. In Figure 4, the PCA accounts for $90 \%$ of the total variance, of which $71 \%$ of $90 \%$ associated with
PC1 and $19 \%$ of $90 \%$ with PC2. Two groups were identifiable in PC1: ARA - TL(F), Hggill(F), HSI(F), Hgmusc(F), Hgliver(F) and $\mathrm{CF}(\mathrm{M})$; $\mathrm{COS}-\mathrm{TW}(\mathrm{M})$, TL, Hggill(M), HSI(M), Hgmusc(M) and Hgliver(M).

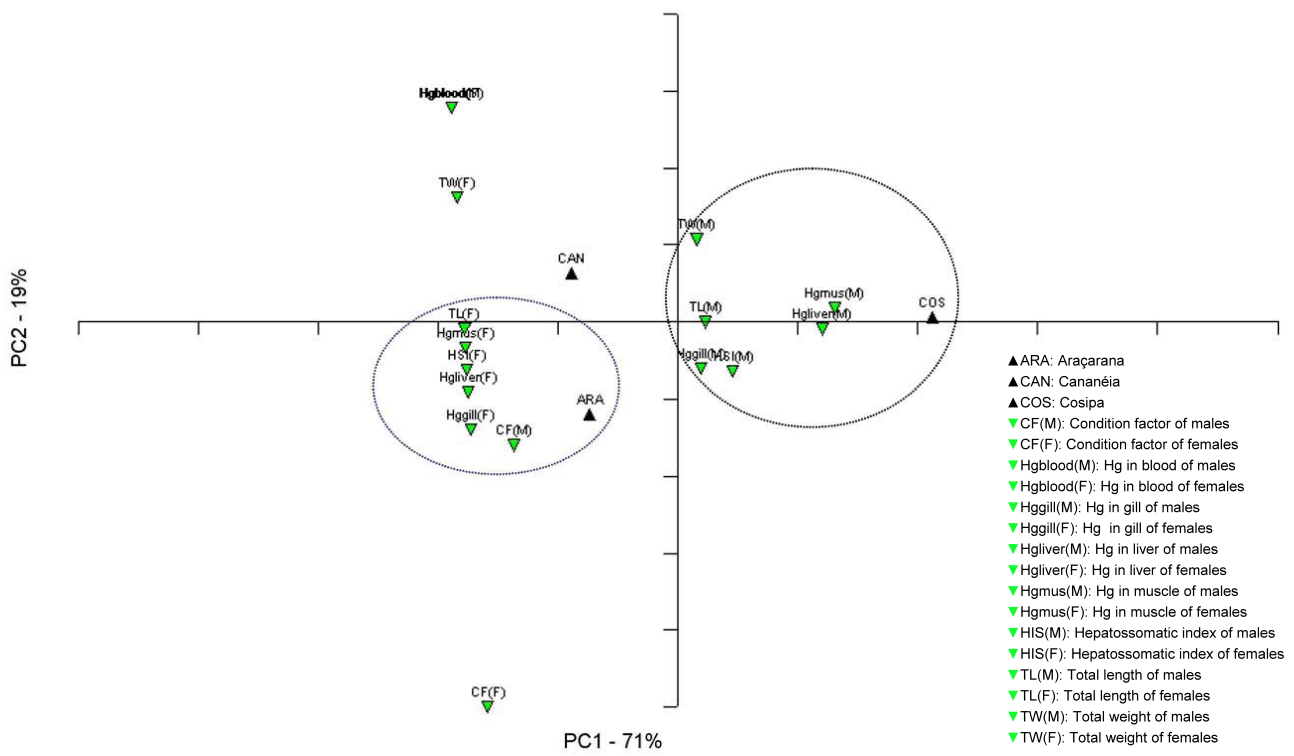

Fig. 4. Principal Components Analysis (PCA) of the biological variables (TL, TW, HSI, CF) and Hg concentrations in gill (Hggill), liver (Hgliver), muscle (Hgmus) and blood (Hgblood) in male (M) and female (F) C. spixii from Cananéia (CAN), industrial (COS) and domestic (ARA) areas. 


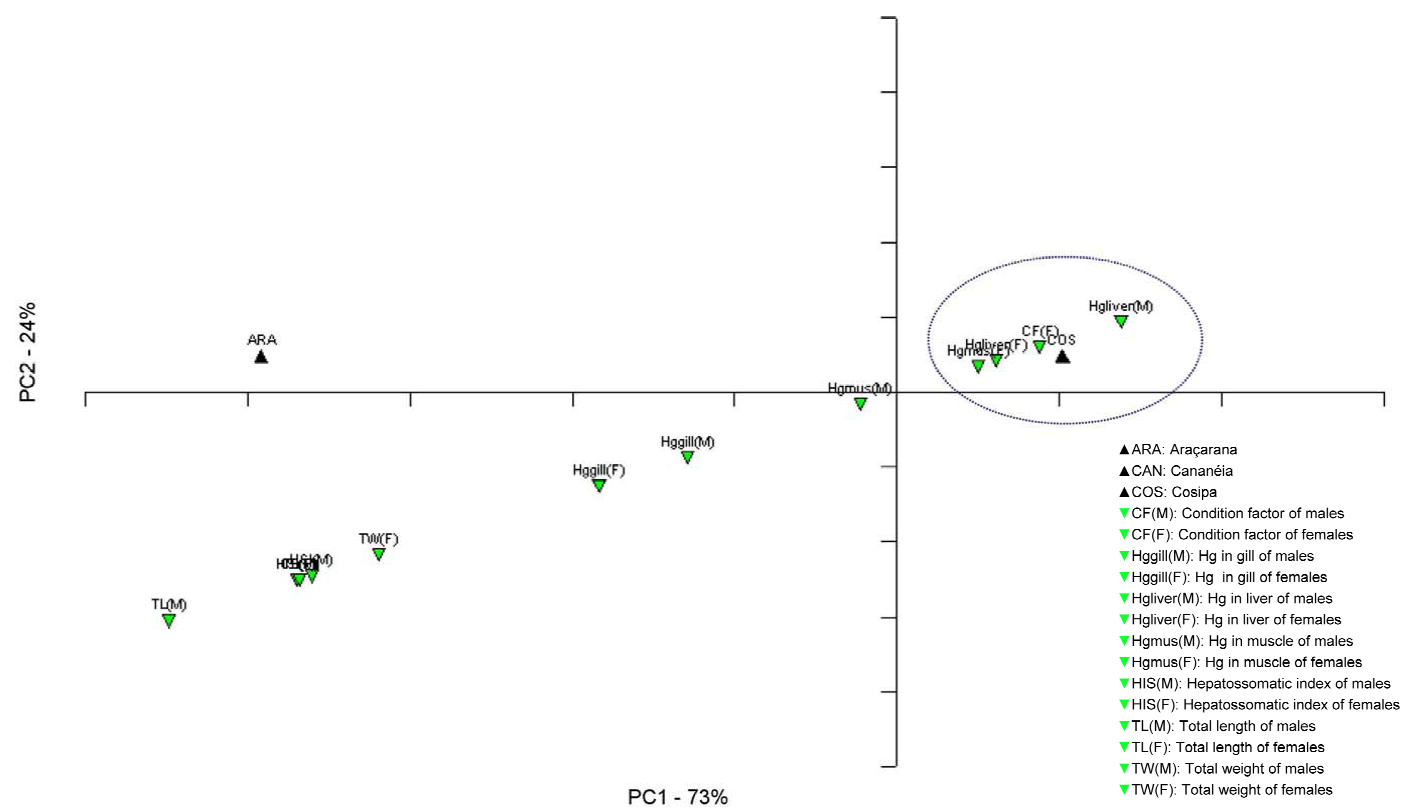

Fig. 5. Principal Components Analysis (PCA) of the biological variables (TL, TW, HSI, CF) and Hg levels in gill (Hggill), liver (Hgliver), muscle (Hgmus) and blood (Hgblood) in male (M) and female (F) G. genidens from industrial (COS) and domestic (ARA) areas.

The same PCA with distinction by gender was analyzed for G. genidens (Fig. 5). Here, PC1 accounted for $73 \%$ of $97 \%$ of the variance and $24 \%$ of $97 \%$ associated with PC2 - both dimensions accounting for $97 \%$ of total variance. For $G$. genidens, one group was observed in PC1: COS - Hgliver(M), $\mathrm{CF}(\mathrm{F})$, Hgliver(F) and $\operatorname{Hgmusc}(\mathrm{F})$. A distinction by gender was also observed between the two species. For all PCAs performed a positive correlation was observed between the different areas and variables of each group.

\section{Discussion}

C. spixii is a good candidate for a bioindicator species because metal accumulation has been observed in its tissues (AZEVEDO et al., 2009a). This potential utility has been further confirmed in the present study which succeeded in detecting $\mathrm{Hg}$ contamination in $C$. spixii and G. genidens (Ariidae) from the Cananéia and Santos-São Vicente estuaries.

The morphological data and somatic indices used in the present study had already been developed for biomonitoring purposes by Adams and Ryon (1994). Azevedo et al. (2009b) recorded higher HSI values in C. spixii from polluted sites in Santos-São Vicente than in fish from a reference (unpolluted) area. However, in the present study no significant differences were observed between the HSI of fish from Santos-São Vicente and of those from the Cananéia estuary. This finding can be explained by sampling period, different abiotic influences and, more specifically, by the high level of individual variation in HSI.

The CF observed in C. spixii from domestic area can suggest either an absence of negative effects or an adaptive response to the presence of domestic sewage. The absence of significant differences observed in all Ariidae catfish can be a consequence of the fish sampled having homogeneous biological conditions. Other factors such as food availability, disease and demographics may also play a major role in determining the $\mathrm{CF}$ of an individual fish.

Although the smallest values of $\mathrm{Hg}$ were found in fish ( $G$. genidens and $C$. spixii) from domestic area, only $C$. spixii showed smaller average length values. This interesting pattern may be indicative of differences in the rates of accumulation of $\mathrm{Hg}$ between the species.

The relative concentrations of $\mathrm{Hg}$ in different tissues (liver >muscle $>$ gill $>$ blood) corroborated the observations of previous studies (e.g. BUSTAMANTE et al., 2003; LICATA et al., 2005; KOJADINOVIC et al., 2007; KASPER et al., 2009). Element turnover rates are, as a general rule, higher in liver than in muscle tissue. Hence, element levels in the muscle better reflect long term intake than do those in other tissues (KOJADINOVIC et al., 2007). 
The PCA analysis confirmed the importance of biological parameters in determining $\mathrm{Hg}$ levels in different tissues for both species. AZEVEDO et al. (2009b) previously used PCA to verify the grouping between biological variables and some biomarkers of metal exposure, such as metallothionein and $\mathrm{d}$ Aminolevulinic dehidratase (ALAD), in $C$. spixii from the Cananéia and Santos-São Vicente estuaries. Our results are consistent with those reported in the literature regarding differences in morphological characteristics and $\mathrm{Hg}$ accumulation in fish (PORVARI, 1995; ALONSO et al., 2000; MOL et al., 2001). The absence of gender differences in $\mathrm{Hg}$ concentration seen in the univariate statistical analysis was interesting, but may have been masked by the influence of other biological or environmental factors. More subtle differences were apparent in the PCA analysis, probably as a consequence of the ability of the statistics to distinguish between the multiple sources of influence.

It is likely that fish with greater $\mathrm{Hg}$ concentrations came from the industrial area, and it is probable that their exposure to mercury in the water caused their contamination. However, it is very important to remember that domestic sewage does not usually contain high quantities of $\mathrm{Hg}$. Rather, mercury contamination is more often caused by industrial sewage and other wastes, as well as atmospheric fallout of pollutants. This study also demonstrates the value of a broad-based bioassessment approach to provide more accurate information on $\mathrm{Hg}$ exposure.

\section{Conclusions}

The $\mathrm{Hg}$ concentrations observed in both species of Ariidae suggest higher exposure or accumulation in $G$ genidens than in $C$. spixii, and reinforce the hypothesis that the industrial area of the Santos-São Vicente estuary system is a source of toxic metal contaminants. Results from the Cananéia estuary also suggest increases in overall $\mathrm{Hg}$ concentrations over time. PCA is a useful tool for the integration of analyses of different biological parameters that may explain variations in $\mathrm{Hg}$ concentration.

\section{ACKNOWLEDGMENTS}

The authors would like to thank the São Paulo Foundation for Research Support -FAPESP for the Post-Doc fellowship to J. S. Azevedo (Process 2008/58261-6) - and the Nuclear and Energy Research Institute for supporting this research.

\section{REFERENCES}

ADAMS, S. M.; RYON, M. G. A comparison of health assessment approaches for evaluating the effects of contaminant-related stress on fish populations. J. Aquatic Ecossyst. Health, v. 3, p. 15-25, 1994.

ADAMS, D. H.; SONNE, C.; BASU, N.; DETZ, R.; NAM, D-H.; LEIFSSON, P. S.; JENSEN, A. L. Mercury contamination in spotted seatrout, Cynoscion nebulosus: An assessment of liver, kidney, blood, and nervous system health. Sci. Total Environ., v. 408, p. 58085816, 2010.

AGUIAR, V. M. C.; BRAGA, E. S. Seasonal and tidal variability of phosphorus along a salinity gradient in the heavily polluted estuarine system of Santos/São VicenteSão Paulo, Brazil. Mar. Pollut. Bull., v. 54, p. 464-488, 2007.

ALONSO, D.; PINEDA, P.; OLIVERO, J.; GONZÁLEZ, H.; CAMPOS, N. Mercury levels in muscle of two fish species and sediments from the Cartagena Bay and the Ciénagas Grande de Santa Marta, Colômbia. Environ. Pollut., v. 109, p. 157-163, 2000.

AZEVEDO, J. S.; FERNANDEZ, W. S.; FARIAS, L. A.; FÁVARO, D. T. I.; BRAGA, E. S. Use of the tropical brazilian fish Cathorops spixii as a bioindicator of trace metals pollution in Santos Bay. Ecotoxicol., v. 18, p. 577-586, 2009a.

AZEVEDO, J. S.; SERAFIM, A.; COMPANY, R.; BRAGA, E.; FÁVARO, D. I.; BEBIANNO, M. J. Biomarkers of exposure to metal contamination and lipid peroxidation in the benthic fish Cathorops spixii from two estuaries in South America, Brazil. Ecotoxicol., v. 18, p. 1001-1010, 2009b.

BOENING, D. W. Ecological effects, transport, and fate of mercury: a general review. Chemosphere, v. 40, p.1335-1351, 2000.

BOLDRINI, C. V.; NAVAS-PEREIRA, D. N. Metais pesados na baía de Santos e estuário de Santos e São Vicente. Ambiente, v.1, n. 3, p.118-127, 1987.

BUSTAMANTE, P.; BOCHET, P.; CHEREL, Y.; MIRAMAND, P.; CAURANT, F. Distribution of trace elements in tissues of benthic and pelagic fish from the Kerguelen Islands. Sci. Total Environ., v. 313, p. 25-39, 2003.

BRAGA, E. S.; FONSECA, A. L. O.; BOSQUILHA, G. E.; DUCATTI, G. M. F.; AGUIAR, V. M. C.; LIMA, C. A. C.; ARASAKI, E. Eutrophication and bacterial pollution assessment risks on the Santos Bay sandy beaches (Brazil): influence of seasonal conditions. J. Coast. Res., v. 35, p. 516-524, 2003.

COELHO, J. P.; SANTOS, H.; REIS, A.T.; FALCÃO, J.; RODRIGUES, E. T.; PEREIRA, M. E.; DUARTE, A. C.; PARDAL, M. A. Mercury bioaccumulation in the spotted dogfish (Scyliorhinus canicula) from the Atlantic Ocean. Mar. Pollut. Bull., v. 60, n. 8, p. 1372-1375, 2010.

ENDO, T.; HISAMICHI, Y.; KIMURA, O.; KOTAKI, Y.; KATO, Y.; OHTA, C.; KOGA, N.; HARAGUCHI, K.Contamination levels of mercury in the muscle of female and male spiny dogfishes (Squalus acanthias) caught off the coast of Japan. Chemosphere, v. 77, p. 1333-1337, 2009. 
FIGUEIREDO, J. L.; MENEZES, N. A. Manual de peixes marinhos do sudeste do Brasil. II. Teleostei (1). São Paulo: Museu de Zoologia da Universidade de São Paulo, 1978. 110 p.

FITZGERALD, W.; ENGSTROM, D. R.; MASON, R. P.; NATER, E. A. The case for atmospheric mercury contamination in remote areas. Environ. Sci. Technol., v. 32, n. 1, p. 1-7, 1998.

FURNESS, R. W.; RAINBOW, P. S. Heavy Metals in the Marine Environment. Boca Raton; Boston: CRC Press, 1990. $256 \mathrm{p}$

HARMELIN-VIVIEN, M.; COSSA, D.; CROCHET, S.; BANARU, D.; LETOURNEUR, Y.; MELLONDUVAL, C. Difference of mercury bioaccumulation in red mullets from the north-western Mediterranean and Black seas. Mar. Pollut. Bull., v. 58, p. 679-685, 2009.

HEATH, A. G. Water Pollution and Fish Physiology. 2. ed.. Boca Raton, Boston: CRC Press, 1995. 245 p.

KARELS, A. E.; SOIMASUO, M.; LAPPIVAARA, J.; LEPPANEN, H.; AALTONEN, T.; MELLANEN, P. OIKARI, A .O. J. Effects of EFC-bleached kraft mill effluent on reproductive steroids and liver MFO activity in populations of pearch and roach. Ecotoxicol., v.7, p. 123-132, 1998.

KASPER, D.; PALERMO, E. F. A.; DIAS, A. C. M I.; FERREIRA, G. L.; LEITÃO, R. P.; BRANCO, C. W. C.; MALM, O. Mercury distribution in different tissues and trophic levels of fish from a tropical reservoir, Brazil. Neotrop. Ichthyol., v. 7, n. 4, p. 751758,2009

KOJADINOVIC, J.; POTIER, M.; LE CORRE, M.; COSSON, R. P.; BUSTAMANTE, P. Bioaccumulation of trace elements in pelagic fish from the Western Indian Ocean. Environ. Pollut., v. 146, p. 548-566, 2007.

LICATA, P.; TROMBETTA, D.; CRISTANI, M.; NACCARI, C.; MARTINO, D.; CALÓ, M.; NACCARI, F. Heavy metals in liver and muscle of Bluefin Tuna (Thunnus thynnus) caught in the straits of Messina (Sicily, Italy). Environ. Monit. Assess., v. 107, n. 1-3, p. 239-248, 2005.

LIMA, A. P. S.; SARKIS, J. E. S.; SHIHOMATSU, H. M.; MULLER, R. C. S. Mercury and selenium concentrations in fish samples from Cachoeira do Piria Municipality, Para State, Brazil. Environ. Res., v. 97, n. 3, p. 236-244, 2005.

MOL, J. H.; RAMLAL, J. S.; LIETAR, C.; VERLOO, M. Mercury fontamination in freshwater, estuarine, and marine fishes in relation to small-scale gold mining in Suriname, South America. Environ. Res. Section A, v. 86, p. 183-197, 2001.
PORVARI, P. Mercury levels of fish in Tucurui hydroelectric reservoir and in River Mojti in Amazonia, in the state of Pará, Brazil. Sci. Total Environ., v. 175, p. 109-117, 1995.

SARDANS, J.; MONTENS, F.; PEÑUELAS, J. Determination of $\mathrm{As}, \mathrm{Cd}, \mathrm{Cu}, \mathrm{Hg}$ and $\mathrm{Pb}$ in biological samples by modern electrothermal atomic absorption spectrometry. Spectrochim. Acta, Part B, v. 65, p. 97$112,2010$.

SCHMIDT, T. C. S.; MARTINS, I. A.; REIGADA, A. L. D.; DIAS, J. F. Taxocenose de bagres marinhos (Siluriformes, Ariidae) da região estuarina de São Vicente, SP, Brasil.Biota Neotrop., v. 18, n. 4, p. 73-81, 2008.

SCHNEIDER, L.; BELGER, L.; BURGER, J.; VOGT, R. C. Mercury bioacumulation in four tissues of Podocnemis erythrocephala (Podocnemididae: Testudines) as a function of water parameters. Sci. Total Environ., v. 407, p. 1048-1054, 2009.

SHAH, A. Q.; KAZI, T. G.; BAIG, J. A.; AFRIDI, H. I.; KANDHRO, G. A.; ARAIN, M. B.; KOLACHI, N. F.; WADHWA, S. K. Total mercury determination in different tissues of broiler chicken by using cloud point extraction and cold vapor atomic absorption spectrometry. Food Chem. Toxicol., v. 48, p. 65-69, 2010.

TIJARO, R.; RUEDA, M.; SANTOS-MARTINEZ, A. Dinâmica poblacional del chivo mapalé Cathorops spixii em la Ciénaga Grande de Santa Marta y complejo de Pajarales, Caribe Colombiano. Bol. Invest. Mar. Cost., v. 27, p. 87-102, 1998.

VAZZOLER, A. E. A DE. Biologia da reprodução de peixes teleósteos: Teoria e Prática. Maringá.: EDUEM, 1996. 169 p.

WANG, R.; WONG, M-H.; WANG, W-X. Mercury exposure in the freshwater tilapia Oreochromis niloticus. Environ. Pollut., v. 158, n. 8, p. 2694-2701, 2010.

WIENER, J. G.; SPRY, D. J. Toxicological significance of mercury in fresh water fish. In: BEYER, W. N.; HEINZ, G. H.; REDMON-NORWOOD, A. W. (Ed.). Environmental contaminants in wildlife interpreting tissue concentrations. Lewis, Boca Raton Publishers, 1996.

(Manuscript received 28 July 2011; revised 03 October 2011; accepted 03 November 2011) 